\section{EDUCATION}

Research, Innovation and Solutions on-line ${ }^{\circledR}$
Electronic Journal of Research

in Educational Psychology



\title{
A model of how motivational strategies related to the expectative component affect cognitive and metacognitive strategies
}

\section{José Manuel Suárez ${ }^{1}$, Ana Patricia Fernández ${ }^{1}$}

${ }^{1}$ Departamento MIDE II (OEDIP), Universidad Nacional de Educación a Distancia (UNED), Madrid

\section{Spain}

Correspondence: José Manuel Suárez Riveiro. C/ Senda del Rey, 7. Facultad de Educación. 28040 Madrid. Spain. Tel. 913988943

E-mail: jmsuarez@edu.uned.es

(C) Education \& Psychology I+D+i and Editorial EOS (Spain) 


\begin{abstract}
Introduction. The topic of self-regulated learning has provided very important information about students' acquisition of knowledge and competences. Traditional research has described the importance of several cognitive, metacognitive, resource control and motivational strategies. Nevertheless, motivational strategies have received less attention in empirical studies. The purpose of this study was to propose a model of how motivational strategies related to the expectative component affect cognitive and metacognitive strategies.
\end{abstract}

Method. 1,080 Spanish-speaking secondary students from different locations throughout Spain provided self-reports on their use of cognitive, metacognitive and motivational strategies. It was assumed that the effect of motivational strategies on cognitive strategies could be mediated by metacognitive strategies. To examine these strategies and their relationships, descriptive statistics were calculated and a path diagram was created.

Results. Information about motivational, metacognitive and cognitive strategies was offered. Results showed significant paths from some motivational strategies, but not all, to metacognitive self-regulation and from metacognitive self-regulation to all of the cognitive strategies. Motivational strategies showed direct and indirect effects on cognitive strategies.

Conclusion. Students should adopt not only cognitive and metacognitive strategies but also other kinds of strategies that allow them to manage their motivation. For example, the generation of a positive expectations strategy can be an important way to improve their learning. This aspect is characteristic of self-regulated learning, which is defined not only by cognitive and behavioural regulation but also by motivational regulation.

Keywords: motivational strategies; motivation; strategies; self-regulated learning 


\section{Un modelo sobre cómo las estrategias motivacionales rela- cionadas al componente de expectativas afectan a las estra- tegias cognitivas y metacognitivas}

\section{Resumen}

Introducción. El tópico del aprendizaje autorregulado ha facilitado información muy relevante sobre la adquisición de conocimiento y de las competencias. La investigación tradicional ha descrito la importancia de varias estrategias cognitivas, metacognitivas, de control de los recursos y motivacionales. Sin embargo, las estrategias motivacionales han recibido menor atención en los estudios empíricos. El propósito de este estudio fue el proponer un modelo de cómo las estrategias motivacionales relacionadas al componente de expectativas afectan a las estrategias cognitivas y metacognitivas.

Método. 1.080 estudiantes de secundaria de toda España facilitaron autoinformes sobre su utilización de estrategias cognitivas, metacognitivas y motivacionales. Se asumió que el efecto de las estrategias motivacionales sobre las estrategias cognitivas podría estar mediado por las estrategias metacognitivas. Para examinar estas estrategias y su relación se obtuvieron estadísticos descriptivos y se elaboró un análisis de senderos.

Resultados. Se ofrece información sobre las estrategias motivacionales, metacognitivas y cognitivas. Los resultados muestran sendas positivas desde algunas estrategias motivacionales, pero no todas, a la autorregulación metacognitiva, y desde la autorregulación metacognitiva a todas las estrategias cognitivas. Las estrategias motivacionales mostraron efectos tanto directos como indirectos hacia las estrategias cognitivas.

Conclusión. Los estudiantes deberían de adoptar no sólo estrategias cognitivas y metacognitivas sino también otros tipos de estrategias que les permitan gestionar su motivación. Por ejemplo, la estrategia de generación de expectativas puede constituir una importante forma de mejorar su aprendizaje. Este aspecto es característico del aprendizaje autorregulado, el cual es definido no sólo por la regulación cognitiva y conductual sino también por la regulación motivacional.

Palabras Clave: estrategias motivacionales; motivación; estrategias; aprendizaje autorregulado

Recibido: $15 / 02 / 11$

Aceptación inicial: 30/02/11

Aceptación final: 07/06/11 


\section{Introduction}

The topic of self-regulated learning has been applied in different settings (De la Fuente \& Eissa, 2010). With respect to learning processes, self-regulated learning has provided very important information about students' acquisition of knowledge and competences. It represents linkages between the different components of learning and suggests an integrative framework. In this way, were proposed several conceptual frameworks or models (Boekaerts \& Niemivirta, 2000; Borkowski, 1996; De la Fuente, Justicia \& Berbén, 2006; Garcia \& Pintrich, 1994; Pintrich, 2000; Schunk \& Zimmerman, 1998; Winne, 1995; Zimmerman, 2000). Its practical value stresses the importance of personal efforts and the personal responsibility of the learner.

Self-regulated learning has described the importance of several cognitive, metacognitive, resource control, and motivational strategies. According to this method, students can achieve success in school by mastering strategies that are well matched to task demands. Cognitive strategies are necessary to learn, remember and understand the material, and include rehearsal, organisation, and elaboration strategies. Metacognitive strategies include students's strategies for planning, monitoring and regulating their cognition to execute cognitive strategies. In this way, metacognition provides personal insights into one's own thinking and fosters independent learning. A great deal of research supports the importance of cognitive and metacognitive strategies in academic learning (Boekaerts, 1996; Schwinger, Steinmayr \& Spinath, 2009; Zimmerman \& Martinez-Pons, 1988, 1990). Finally, motivational strategies can be used by students to elicit cognitions and emotions with respect to learning activities (Garcia \& Pintrich, 1994). Thus, students can actively adapt or change their strategies as a function of both personal and contextual factors, and they can always learn new strategies.

Nevertheless, motivational strategies have received less attention in empirical studies. In previous studies, Suárez \& Fernández $(2005,2011)$ elaborated several scales to measure motivational strategies. They found that motivational strategies were related to expectancy, value and affect, following the socio-cognitive model of motivation (Pintrich, 1988a, 1988b). In the present work, we carry out a study about motivational strategies related to the expectancy component, which includes several strategies (Suárez \& Fernández, 2005, 2011). The generation of positive expectations strategy involves creating thoughts and beliefs that help 
the student to successfully accomplish the task. Moreover, there is a wide relationship between students' expectations, parents' expectations and academic achievement (p.e., Zhang, Haddad, Torres y Chen, 2011). The defensive-pessimism strategy creates negative expectations that serve to motivate and promote greater efforts before performance to avoid failure. Defensive-pessimism is predicted by fear of failure and negatively predicted by competence valuation, self-concept, enjoyment and intentions to participate (p.e., Ntoumanis, Taylor \& Standage, 2010). The self-handicapping strategy creates an excuse for or an obstacle to potential failure so that students are provided with beneficial attributions to maintain self-worth and positive self-schemas. For example, low effort can be used to prevent a student from being responsible for failure. A number of characteristics have been related to self-handicapping as fear of failure, a heightened sensitivity to shame and embarrassment upon failure (p.e., Ntoumanis, Taylor \& Standage, 2010). The generation of external attributions strategy focuses on creating explanations for results, the causes of which are external to the student. Thus, external learning attribution such as attributing success and failure to situation and fortunate is associated with worse self-regulated learning (p.e., Wang et al., 2010). The selfaffirmation strategy activates positive conceptions of the self to maintain self-worth when an individual experiences a negative evaluation in a particular and valued domain. However, it is demonstrated that different types of self-affirmation procedures produce different effects (p.e., Stapel \& Van der Linde, 2011) Through the enhancement of others strategy, the students in low achievement situations enhance the capabilities of their classmates to protect the selfvalues of others. This motivational strategy is related with achievement goal orientation and self-protection (Suárez \& Fernández, 2005). The annulation of others involves a student denying or minimising the capabilities of classmates to protect his or her own self-value from situations in which comparison is possible (Suárez \& Fernández, 2005).

\section{Questions of this study}

It is important to examine the motivation-cognition strategies interface to determine whether students can regulate motivation as well as cognition. The regulation of motivation may moderate the deployment of the cognitive and metacognitive strategies (Bartels, MagunJackson \& Kemp, 2009), more typically focused in discussions of learning. The general question is this: how does regulation of motivation influence the regulation of cognition and metacognition? Therefore, the main purposes of this study were to describe the use of motivational strategies; provide support for the relationship among motivational, metacognitive and cogni- 
tive strategies; and propose a model of the mechanism by which motivational strategies related to the expectative component affect metacognitive and cognitive strategies.

\section{Method}

\section{Participants}

Participants were 1,080 Spanish-speaking secondary students from locations throughout Spain. There were 498 males and 582 females, ranging in age from 14 to 19 years.

\section{Procedure}

Testing was voluntary. Students were assured that their responses were confidential and that only the researchers would have access to the data. They were told that this was not a test, so they completed the questionnaires anonymously. Finally, they were also informed that there were no right or wrong answers, but only statements that reflected their behaviours while learning and studying.

All students completed two questionnaires in their regular classrooms and were assured of confidentiality. Here, we will focus only on those variables and results that are crucial for the present study.

\section{Instruments}

Cognitive strategies (rehearsal, organisation, and elaboration) and metacognitive strategies were assessed with the Spanish version of the Motivated Strategies for Learning Questionnaire (MSLQ. Pintrich, Smith, Garcia \& McKeachie, 1993). All items were answered on a five-point scale ranging from 1 (rarely) to 5 (very often). Cronbach alpha coefficients obtained in the present study were .68 for rehearsal, .80 for organisation, .82 for elaboration and .66 for metacognitive strategies.

Motivational strategies were assessed with the secondary version of the expectancy scale of EEMA, Escalas de Estrategias Motivacionales del Aprendizaje-Versión Secundaria (Suárez \& Fernández, 2011; in english, the Motivational Strategies of Learning Scales- 
Secondary Versión). A translation of all items is provided in Appendix I. Items were answered on a five-point scale ranging from 1 (completely disagree) to 5 (completely agree). Cronbach alpha coefficients obtained in the present study were .60 for generation of positive expectations, .52 for defensive pessimism, .45 for self-handicapping, .50 for generation of external attributions, .41 for self-affirmation, .69 for enhancement of others and .62 for annulation of others.

\section{Statistical analysis}

First, internal consistency was calculated using Cronbach’s Alpha. Second, descriptive statistics were calculated to study the different types of cognitive, metacognitive and motivational strategies. And finally, a path diagram was created to examine relationships between these strategies. It was assumed that the effect of motivational strategies on cognitive strategies could be mediated by metacognitive strategies.

\section{Results}

\section{Descriptive statistics and gender differences}

Means, standard deviations, and intercorrelations can be seen in Table 1. Most of the seven motivational strategies are positively correlated to a moderate or high degree. Negative correlation between the generation of positive expectations and the enhancement of others is the only exception. Regarding the mean frequency reported by students about the seven motivational strategies, generation of positive expectations is the most used motivational strategy followed by generation of external attributions. And enhancement of others is the least used followed by self-handicapping. 
Table 1. Scale means, standard deviations, and intercorrelations.

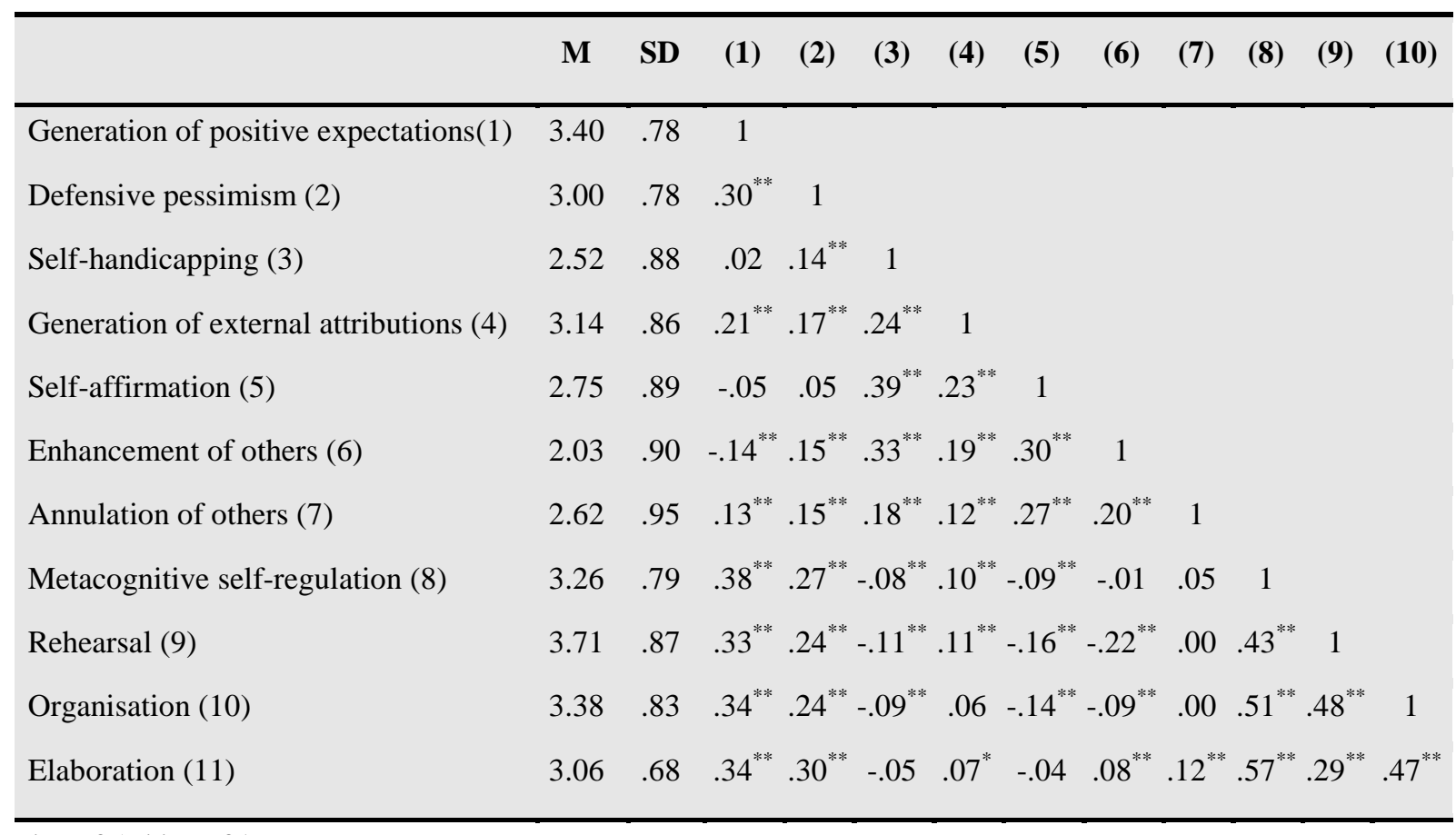

$* \mathrm{p}<.05 * * \mathrm{p}<.01$

Gender differences were examined using $t$ tests to compare boys and girls on each of the seven motivational strategies. Boys and girls did not differ in their use of defensive pessimism, self-handicapping, and generation of external attributions strategies. There were, however, gender differences in generation of positive expectations, self-affirmation, enhancement of others, and annulation of others. Boys $(M=2,85 ; M=2,14$; and $M=2,77)$ rated themselves using self-affirmation, enhancement of others, and annulation of others strategies more than girls $\operatorname{did}(M=2,68 ; M=1,96 ;$ and $M=2,55), t(1080)=3,26, \mathrm{p}<.01 ; t(1080)=3,33, \mathrm{p}<.01$; $t(1080)=4 \mathrm{p}<.001$. Girls $(\mathrm{M}=3,44)$ reported using generation of positive expectations strategy more than boys $(M=3,34), t(1080)=2.29, \mathrm{p}<.05$.

\section{Model of motivational strategies effect on metacognitive and cognitive strategies}

To test the relationships between strategies, a path diagram was specified in AMOS 17. In this model, cognitive strategies were predicted by metacognitive self-regulation and motivational strategies. The findings suggest that the model in Fig. 1 fits the data acceptably $\left(\chi^{2}(12)=18,58, p=0.10\right)$. Corroborating evidence is provided by fit statistics $(\mathrm{CFI}=0.99$, GFI=0.99, AGFI=0.98, RMSEA=.02, CFI= .99). 
Results showed significantly positive paths from two motivational strategies (generation of positive expectations and defensive pessimism) and a significantly negative path from one motivational strategy (self-handicapping) to metacognitive self-regulation. Also as expected, results showed significantly positive paths from metacognitive self-regulation to all of the cognitive strategies (rehearsal, organisation, and elaboration).

Furthermore, motivational strategies showed positive paths from two motivational strategies, generation of positive expectations and defensive pessimism, to all of the cognitive strategies; from generation of external attributions to rehearsal; and from annulation of others to elaboration. By contrast, other motivational strategies showed negative paths; selfaffirmation to rehearsal and organisation, and self-handicapping to elaboration reveal this trend. The enhancement of others strategy showed a positive path to elaboration and a negative path to rehearsal. 


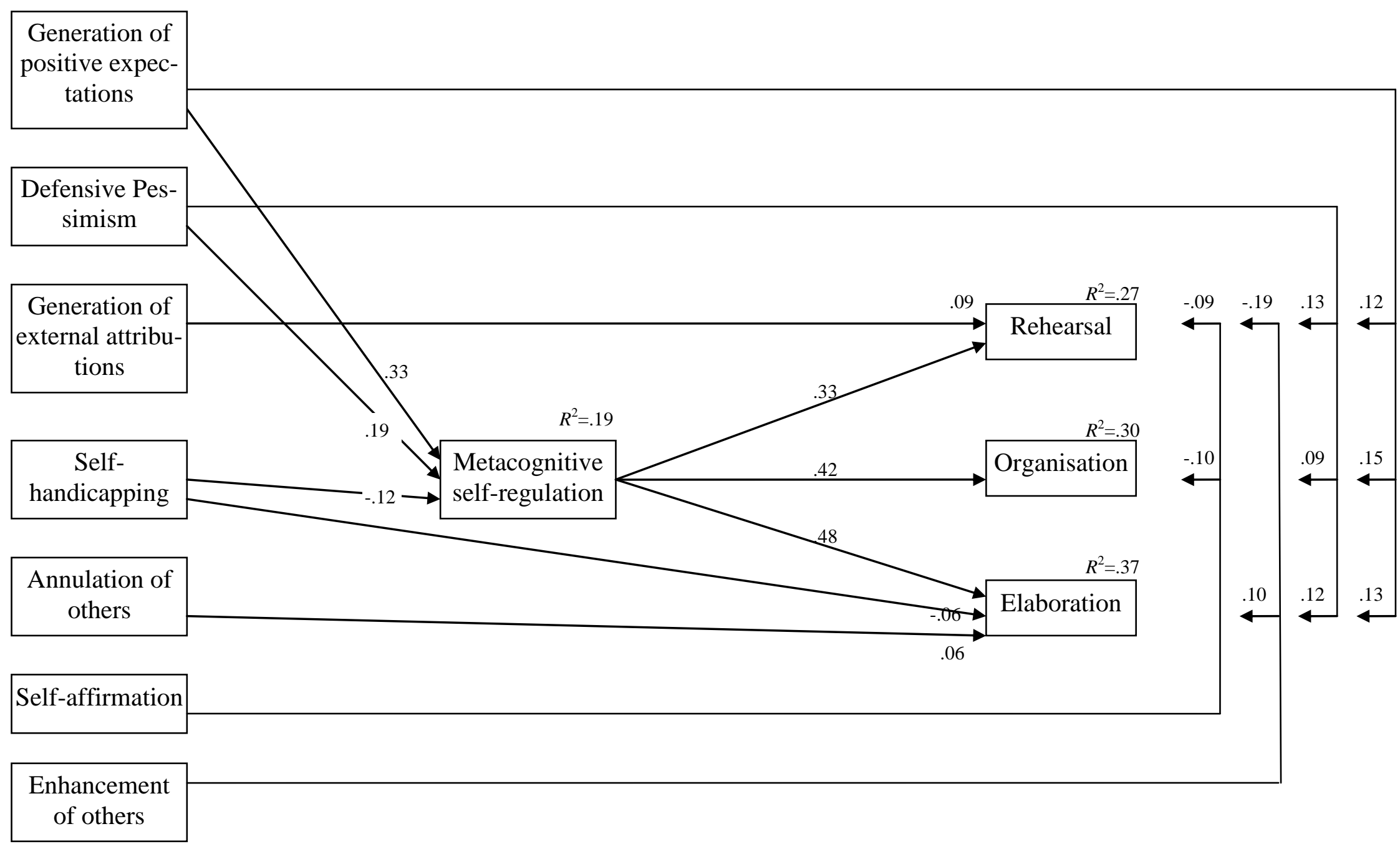

Figure 1. Path model of the relationship among motivational, metacognitive and cognitive strategies. Only significant standardised regression coefficients $(\mathrm{p}<.01)$ are shown in the model. Correlations are omitted for simplicity of representation. 
Therfore, motivational strategies showed both direct and indirect paths to cognitive strategies. As expected, the squared multiple correlation of metacognitive self-regulation (the proportion of its variance that is accounted for by its predictors) shows that the endogenous variable is not predicted very accurately by the motivational strategies in the model. To increase this proportion, it would be necessary to consider other motivational strategies (Suárez \& Fernández, 2005) and motivational variables (Suárez, González \& Valle, 2001), for example, academic goals, academic self-concepts and attributions.

\section{Discussion and Conclusions}

The study had three purposes. The first was to describe the use of several motivational strategies in our sample and the existence of differences in gender. The second was to provide empirical support for the relationship among motivational strategies and metacognitive and cognitive strategies. The third goal was to propose a model for these relationships. In this model, metacognitive regulation functions as a moderator for the effect of some motivational strategies on cognitive strategies. This research attempts to highlight the importance of motivational strategies and self-regulation and after analysing the results, we are confident that we achieved our purposes.

Results found in this study suggest that the more used motivational strategie is generation of positive expectations and the less used is enhancement of others, and gender differences in the use of motivational strategies were found. We consider that in future studies it would be useful to contrast this information with other samples and confirm if the otbtained gender differences might affect the use of metacognitive and cognitive strategies.

In line with our predictions, the mediation of motivational strategies was found for some strategies (generation of positive expectations, defensive pessimism and selfhandicapping) but not all. Noteworthy features of this model include the high positive relationship between generation of positive expectations and metacognitive self-regulation, the negative relationship between self-handicapping and metacognitive self-regulation, the high relationships between metacognitive self-regulation and all of the cognitive strategies, and the direct and indirect effects from motivational strategies to cognitive strategies. 
Therefore, students regulate their learning not only by use of cognitive and metacognitive strategies but also by motivational strategies. Thus, students should not only adopt cognitive and metacognitive strategies in their learning but also other kinds of strategies that allow them to manage their motivation and increase the use of cognitive and metacognitive strategies. For example, the generation of positive expectations strategy can be an important tactic to improve learning. This aspect characterises self-regulated learning, which is defined not only by cognitive, metacognitive and behavioural regulation, but also by motivational regulation.

Further research is need to better understand why students use some of these motivation strategies and how instructors can empower students by giving them control over their learning with the use of these motivational strategies, for example, increasing their perceptions of success.

Nevertheless, we must consider some limitations of this study that need to be addressed by future research. First, althought this research attempts to highlight the importance of motivational strategies and self-regulation, traditional school instruction continues to be typically characterised by strong external control, where the teacher regulates students' learning processes. Under such circumstances, investigation of self-regulation and their results may be limited in real educative contexts, so it is important to encourage both researchers and instructors to reflect on their studies and teaching these kind of findings and relationships.

Second, with respect to the instruments, several reliabilities were below to the common .70 or .60 minimum. Validity evidence is very important when using self-report instruments, particularly when these instruments are not supplemented by other measures (Winne \& Perry, 2000). In this way, students could not be reliable reporters of their self-regulated learning activity (Winne \& Jamieson-Noel, 2002) and can use strategies in ways that are task- and domain-specific.

Finally, Structural Equation Modelling models can never be accepted, they can only fail to be rejected. We need to explore in more detail the way in which motivational strategies affect self-regulated learning processes and motivation. Furthermore, longitudinal studies are required to confirm and understand issues of causality. 


\section{References}

Bartels, J.M., Magun-Jackson, S. \& Kemp, A.D. (2009). Volitional regulation and selfregulated learning: An examination of individual differences in approach-avoidance achievement motivation. Electronic Journal of Research in Educational Psychology, $7(2), 605-626$.

Boekaerts, M. (1996). Self-regulated learning at the junction of cognition and motivation. European Psychologist, 2, 100-112.

Boekaerts, M. \& Niemivirta, M. (2000). Self-regulated learning: finding a balance between learning goals and ego-protective goals. In M. Boekaerts, P.R. Pintrich \& M. Zeidner (Eds.), Handbook of Self-regulation (pp. 417-450). San Diego, CA: Academic Press.

Borkowski, J. G. (1996). Metacognition: theory or chapter heading? Learning and Individual Differences, 8, 391-402.

De la Fuente, J. \& Eissa, M. A. (Eds.) (2010). International Handbook of Perspectives on Applying Self-Regulated Learning in Different Settings. Almería: Education \& Psychology I+D+i; e-Publishing Series.

De la Fuente, J., Justicia, F. \& Berbén, A.B.G. (2006). An interactive model of regulated teaching and self-regulated learning. International Journal of Learning, 12(7), 217-225.

Garcia, T. \& Pintrich, P.R. (1994). Regulating motivation and cognition in the classroom: The role of self-schemas and self-regulatory strategies. In D.H. Schunk \& B. J. Zimmerman (Eds.), Self-regulation of learning and performance: Issues and educational applications (pp. 127-154). Hillsdale, New Jersey: Lawrence Erlbaum Associates.

Ntoumanis, N., Taylor, I. M. \& Standage, M. (2010). Testing a model of antecedents and consequences of defensive pessimism and self-handicapping in school psychical education. Journal of Sports Sciences, 28, 1515-1525.

Pintrich, P. R. (1988a). A process-oriented view of student motivation and cognition. In J. Stark \& L. Mets (Eds.), Improving teaching and learning through research: New directions for institutional research (Vol. 57, pp. 65-79). San Francisco: Jossey-Bass.

Pintrich, P. R. (1988b). Student learning and college teaching. In R.E. Young \& K.E. Eble (Eds.), College teaching and learning: Preparing for news commitments. New directions for teaching and learning (Vol. 33, pp. 71-86). San Francisco: Jossey-Bass. 
Pintrich, P. R. (2000). The role of goal orientation in self-regulates learning. In M. Boekaerts, P. R. Pintrich \& M. Zeidner (Eds.), Handbook of Self-regulated learning (pp. 451502). San Diego, CA: Academic Press.

Pintrich, P. R., Smith, D., Garcia, T. \& McKeachie, W. (1993). Predictive validity and reliability of the Motivated Strategies for Learning Questionnaire. Educational and Pshychological Measurement, 53, 801-813.

Schunk, D.H. \& Zimmerman, B.J. (Eds.) (1998). Self-regulated learning: From teaching to selfreflective practice. New York: Guilford.

Schwinger, M., Steinmayr, R. \& Spinath, B. (2009). How do motivational regulation strategies affect achievement: Mediated by effort management and moderated by intelligence. Learning and Individual Differences, 19, 621-627.

Stapel, D.A. \& Van der Linde, L.A.J.G. (2011). What drives self-affirmation effects? On the importance of differentiating value affirmation and attribute affirmation. Journal of Personality and Social Psychology, 101(1), 34-45.

Suárez, J. M. \& Fernández, A. P. (2005). Escalas de evaluación de las estrategias motivacionales de los estudiantes. Anales de Psicología, 21(1), 116-128.

Suárez, J. M. \& Fernández, A. P. (2011). Evaluación de las estrategias de autorregulación afectivo-motivacional de los estudiantes: Las EEMA-VS. Anales de Psicología, 27(2), 369-380.

Suárez, J. M., González, R. \& Valle, A. (2001). Multiple-goal pursuit and its relation to cognitive, self-regulatory, and motivational strategies. British Journal of Educational Psychology, 71, 561-572.

Wang, J., Zhang, W., Zhu, Z., Zhen, S., Mai, Y. \& Li, D. (2010). A modulating model for the impacting factors in self-regulated learning of college students. Acta Psychologica Sinica, 42(2), 262-270.

Winne, P. (1995). Inherent details in self-regulated learning. Educational Psychologist, 30(4), 173-187.

Winne, P. \& Jamieson-Noel, D. (2002). Exploring students' calibration of selfreports about study tactics and achievement. Contemporary Educational Psychology, 27, 551-572.

Winne, P. \& Perry, N.E. (2000). Measuring self-regulated learning. In M. Boekaerts, P. Pintrich \& M. Zeidner (Eds.), Handbook of self-regulation (pp. 561-566). San Diego, CA: Academic Press.

Zhang, Y., Haddad, E., Torres, T. \& Chen, Ch. (2011). The reciprocal relationships among parents' expectations, adolescents' expectations, and adolescents' achievement: A two- 
wave longitudinal analysis of the NELS data. Journal of Youth and Adolescence, 40(4), 479-489.

Zimmerman, B.J. (2000). Attaining self-regulation. In M. Boekaerts, P.R. Pintrich \& M. Zeidner (Eds.), Handbook of Self-regulation: Theory, research and applications (pp. 13-39). San Diego, California: Academic Press.

Zimmerman, B.J. \& Martinez-Pons, M. (1988). Construct validation of a strategy model of student self-regulated learning. Journal of Educational Psycholgy, 80, 284-290.

Zimmerman, B.J. \& Martinez-Pons, M. (1990). Student differences in self-regulated learning: Relating grade, sex and giftedness to self-efficacy and strategy use. Journal of Educational Psychology, 82(1), 51-59. 


\section{Appendix I. Traduction of the EEMA-VS (Escalas de Estrategias Motivacionales del Aprendizaje-Versión Secundaria) Expectancy Scale.}

1. I try to ignore the academic performance of the rest and in this way see myself as more competent. (Annulation of others)

2. On occasion, I try to excuse my academic performance saying that I was unwell. (Selfhandicapping)

3. When my academic results are negative, I try to avoid thinking about it to not feel bad. (Self-affirmation)

4. I try not to value the successes of the others, and in this way I see myself as a better student. (Annulation of others)

5. When facing a difficult task or subject, I think about other similar situations in which the tasks ultimately did not turn out to be so difficult as I believed initially. (Generation of positive expectations)

6. I have the habit of imagining the results that I can achieve in the worst possible scenario and use this as motivation for my studies. (Defensive pessimism)

7. When I obtain negative results in certain tasks or subjects, I try not to give it too much importance and think about other tasks or subjects in which I perform well. (Self-affirmation)

8. Often I think that I am unlucky that my classmates have a high capacity for learning which prevents me from standing out more. (Enhancement of others)

9. To motivate myself before some tasks, I think that if the teacher is not very demanding I will obtain a good result. (Generation of external attributions)

10. I try to ignore the academic qualities of the others and in this way see myself as more competent. (Annulation of others)

11. When facing a task or subject, I think that I am capable of exerting sufficient effort to be successful. (Generation of positive expectations)

12. Sometimes I deliberately do not put effort into tasks, so that if my results are not good I can say that it was due to the fact that I did not try sufficiently. (Self-handicapping)

13. When I have bad grades or results, I am in the habit of justifying myself, thinking that academic success isn't as important for me as other aspects of my life. (Self-affirmation)

14. To motivate myself before tasks, I think that with luck I will obtain a good result. (Generation of external attributions)

15. When I face a difficult task or subject, I think that I have the necessary aptitude to be successful. (Generation of positive expectations) 
16. Sometimes I say that I am not good at a task or subject, but actually, what I am doing is demanding a major effort of myself. (Defensive pessimism)

17. To motivate myself before tasks, I think that if they are not difficult, I will obtain a good result. (Generation of external attributions)

18. When I don't obtain good academic results, I think that if I was in another classroom, I would have greater success, because some of my current classmates are very good students. (Enhancement of others)

19. When I face a difficult task, I think about similar situations in which I was successful. (Generation of positive expectations)

20. I enhance the academic qualities of others to convince myself that if I don't obtain better grades the problem is not me, but rather the competence of some of my classmates. (Enhancement of others)

21. I use to have doubts about the academic results that I could reach, but actually I do this to enhance the need for doing my best. (Defensive pessimism)

22. I use to think that if I did not stand out more in studies, this was due to the fact that my other classmates were very good students. (Enhancement of others)

23. Sometimes I delay completing my academic tasks on time, so that if my results are not as good as I expected, I can say that the reason was the lack of time. (Self-handicapping)

24. I use to give a pessimistic image of the results that I can achieve, but later I obtain good grades. (Defensive pessimism)

Note: In parentheses is indicated the corresponding motivational strategy. 
José Manuel Suárez and Ana Patricia Fernández

[This page intentionally left blank] 